\title{
ANALYSIS ON ENTREPRENEURIAL INTENTION, MOTIVATION AND PERSONALITY TRAITS: STUDY AT UNIVERSITAS INDONESIA
}

\author{
Razanah Mahdi M., Eko Sakapurnama \\ Department of Business Administration Science, Faculty of Administrative \\ Sciences, University of Indonesia.
}

\begin{abstract}
In the era of disruption, organization needs people who posses the entrepreneurial profile. The study aims to provide a general description on the level of entrepreneurial intention, motivation, and personality traits of final years students of the University of Indonesia. Entrepreneurial Intention is measured by two dimensions, i.e. Immediate Term Intention and Future Intention. Meanwhile, Entrepreneurial Motivation is measured by three dimensions, namely Ambition for Freedom, Self-Realization, and Pushing Factors. Personality Traits are measured by four dimensions, namely Personality Traits, Business Relation, Behavior in Organization, and Other Characteristics. The study compiled as respondents 150 final year students from 5 faculties, namely: Faculty of Economics and Business, Faculty of Administrative Science, Faculty of Pharmacy, Faculty of Computer Science and Faculty of Engineering. Afterwards, it applied mean value to analyze respondents' answers. The results show that final year students from the Faculty of Economics and Business, Faculty of Administrative Science, Faculty of Pharmacy, Faculty of Computer Science and Faculty of Engineering, have high intention, high motivation, as well as strong personality to become entrepreneur.
\end{abstract}

Keywords: Entrepreneurship; Entrepreneurial Intention; Entrepreneurial Motivation; Entrepreneurial Personality Traits. 


\section{INTRODUCTION}

Recent study showed that nowadays companies require people who posses entrepreneurial competences and mindset that can serve as a leverage for business competitiveness (Abdillah, Sakapurnama, 2017). Entrepreneurship (kewirausahaan in Indonesian) is defined by Robbin \& Coulter (2002) as a process in which an individual or a group of individuals applies organized measures and media to seek opportunity to create values and grow to satisfy his/ her desire and need, through innovation and uniqueness, regardless the resources under his/her control. Entrepreneur (wirausaha) is defined as an individual who utilizes market opportunity through technical innovation or organizational innovation (Schumpeter, 1934).

There is a relation between entrepreneurship and the economy of a country. As Schumpeter (1934) suggested, i.e. entrepreneurship has big contribution to economic development through its creation of innovation, employment, and prosperity. Another study conducted by Kasseeah (2016) shows that there are positive impacts generated by entrepreneurs to the financial growth and development of a country, and hence entrepreneurs are an important ingredient that contributes to a country's economic growth and development.

The Central Bureau of Statistics (BPS) Republic of Indonesia recorded that the total number of businesses which operate by entrepreneurs in Indonesia in 2016 was $3.1 \%$. This ratio has actually surpassed the minimum number of business owner required to exist in a country to progress, which is $2 \%$. However, the percentage of entrepreneurs in Indonesia is still lagging behind other countries, such as Malaysia (5\%), Singapore (7\%), China (10\%), Japan (11\%), and USA (12\%) (see figure .1).

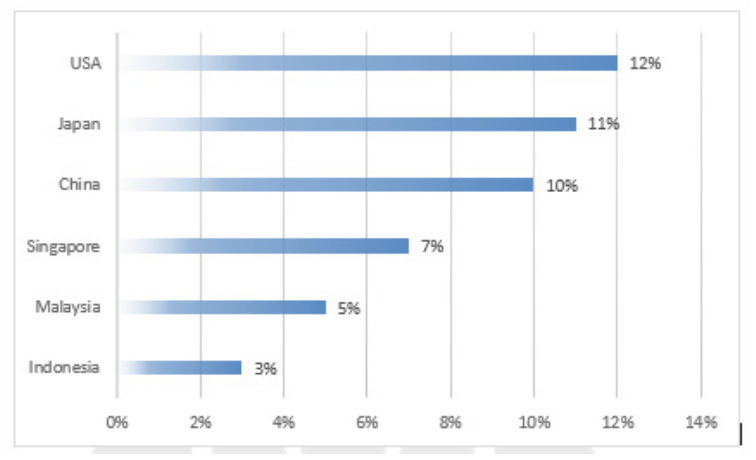

Figure 1. Ratio of Number of Entrepreneur to Population Among Countries

Source: Ministry of Cooperatives and SME's (2017)

In addition, when compared to the total population of Indonesia, which amounts 252 million people, the percentage of non-agricultural entrepreneurs in Indonesia remains very low, which is 7.8 million (www.depkop.go.id, 2017). Thus, the number of entrepreneurs must be increased in order to reduce unemployment level, as well as push forward the national economy.

It is to believe that higher education as a center of excellence, often creates various innovations and is considered to be an agent that transforms a civilization of a country (Philpott, dkk, 2011; Fayolle dan Redford, 2014). Morever, Fayolle and Redford (2014) argue that today's universities need to become more entrepreneurial oriented, change their strategies, structures and practices, change their culture and help students and faculty members to develop their entrepreneurial mindset and entrepreneurial actions.

University is one of the platforms that plays an important role in growing entrepreneurial intention among the students, as it has an important role in cultivating entrepreneurial mentality to its students, i.e. to build their courage and confidence to start becoming an 
entrepreneur (Etzkowitz, 2003). Dikti (Directorate of Higher Education) as a higher education institution supports university's roles in improving entrepreneurship among university students, increasing competitiveness and quality of university graduates, through the Indonesian Students Entrepreneurship Program (PKMI) which was just revitalized in 2017. A study was conducted by Putranto, I.J, and Sakapurnama, E (2016) to 150 students from Faculty of Social Sciences and Humanities on entrepreneurship profile among final year students of University of Indonesia. The result shows that the final year students of University of Indonesia from the Faculty of Social Sciences and Humanities have high entrepreneurial profile level, with average final score of 3.76. University of Indonesia is one of the campuses that supports entrepreneurship, as has been written in one of its strategic objectives, which is "improving research culture and quality, entrepreneurial spirit, innovation, effectiveness, and producing breakthrough and applicable ideas for community service" (https://own.ui.ac. id, 2017), which shows that the university encourages its students to become entrepreneur. In addition, the

University of Indonesia also serves as a platform to build entrepreneurial character of the students by providing facilities to cultivate knowledge and support business development, which is shown by, among others, the existence of Center for Entrepreneurship Development and Studies (CEDS) in UI and UKM Center in FEB UI (Faculty of Economics and Business), as well as curriculum associated with entrepreneurship in several other faculties, or competitions related to business plan, and entrepreneurship seminars, which serve to expand students' knowledge as well as motivate and grow their interest to become entrepreneurs.

This study analyzes the level of interest, motivation, and personality associated with entrepreneurial characteristics of final year undergraduate students of the UI, particularly those from the Faculty of Economics and Business, Faculty of Administrative Science, Faculty of Pharmacy, Faculty of Computer Science, and Faculty of Engineering. The importance of measuring entrepreneurial intention was expressed by Krueger et al (2000) in Ng KimSoon (2016), who argued that intention is the best predictor for a planned behavior, such as entrepreneurship. Intention to become entrepreneur is associated with an individual's tendency to start entrepreneurial activities in the future. (Davidson,1995). Krueger and Carsrud (1993) in Ng Kim-Soon (2016) studied about criticism against studies on entrepreneurial intention as behavior predictor, mainly due to its lack of connection with future actions; they argued that motivation pushes us toward a certain behavior, which thus gives connection between intention and behavior. The importance of entrepreneurial motivation is also expressed by other researchers, such as Ajzen (1991), who argued that one of the basic factors that influences behavior is motivation, and it is assumed that motivational factors influence and shape intention toward a certain behavior. Schumpeter defines an entrepreneur as a special individual or at least one that is emotionally and psychologically different from salary manager (Baum, et al, 2007; in Galloway 2009). Thus, the researcher conducted this study on entrepreneurial intention, motivation and personality that are related to entrepreneurship to get a description of the level of entrepreneurial intention, motivation and personality traits to produce knowledge for the university 
regarding the intention, motivation, and personality of the students associated with entrepreneurship so as to enable the university to create a proper program that can increase students' positive attitude and intention to become entrepreneur, and make entrepreneurship as one of their career options, as well as as predictor of entrepreneurial potentials of the final year students in the University of Indonesia.

Based on the above background, there are three problems addressed in this study, which are; first to measure how is the general condition of entrepreneurial intention among the final year students of Undergraduate Program of Faculty of Economics and Business, Faculty of Administrative Science, Faculty of Pharmacy, Faculty of Computer Science, and Faculty of Engineering of the University of Indonesia. Secondly, this study also focusses on the entrepreneurial motivation among the final year students of Undergraduate Program of Faculty of Economics and Business, Faculty of Administrative Science, Faculty of Pharmacy, Faculty of Computer Science, and Faculty of Engineering of the University of Indonesia. Thirdly, this research conducts to answer how is the general condition of personality associated with entrepreneurship among the final year students of undergraduate program of Faculty of Economics and Business, Faculty of Administrative Science, Faculty of Pharmacy, Faculty of Computer Science, and Faculty of Engineering of the University of Indonesia.

Intention is a motive that indicates a direction of an individual's attention toward an object he/she deems attractive and fun. If an individual is interested in a certain activity or object, he/she will tend to be engaged more actively with such an activity or object. (Hurlock, 1991). Entrepreneurial Intention is defined by Santoso (1939) and Fuadi (2009) as a desire, interest, and willingness to work hard or be strongly driven to do maximum efforts to meet one's life needs without being afraid of the possible risks, as well as be strongly driven to learn from failure.

Kim Soon et.al (2016) in his study divided entrepreneurial intention into two dimensions, namely Immediate Term Intention, which is a shortterm intention or intention to become entrepreneur in the near future, and Future Intention, which is a long-term intention to become entrepreneur or intention to become entrepreneur in the future. Other variables needs to explain in this research is entrepreneurial motivation and personality traits.

Motivation is defined as the willingness to do something, while motive refers to need, desire, drive, or impulse. An individual's motivation is influenced by his/her motive power. An individual's behavior is determined by a very powerful motive. A very strong motive will usually decline after it is satisfied, or when it faces failure (Buchari Alma, 2007). Furthermore, personality is defined as a dynamic organization of an individual psycho-physical system that determines an individual's thought and behavior in unique manner (Gordon W. Allport in Yosep, 2003). Personality has something to do with one's career option, including his/her decision to become entrepreneur. As suggested by Anoraga (2009), in choosing a job, an individual is usually influenced by his/her personality. In addition, various studies revealed that personality traits are prerequisites needed to start an entrepreneurial activity (McCelland 1961; Hisrich and Peters 1989, in Venesaar et.al, 2006).

Framework of thinking is a conceptual model on how a theory is associated with various factors that have been identified as an important problem. This study 
aims to measure intention, motivation, and personality traits associated with entrepreneurship. An individual who becomes an entrepreneur must have it all started by intention.

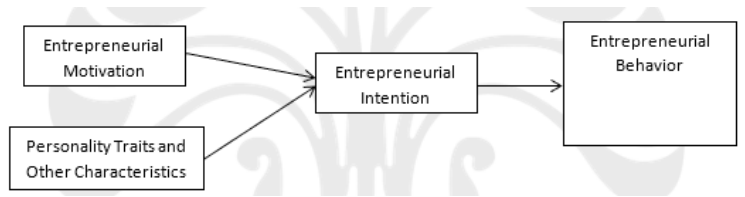

Figure 2 . The Relations between Intention, Motivation, and Personality Traits and Other Characteristics toward Entrepreneurial Behavior

Source: Results processed by researcher, 2017

The Theory of Planned Behavior is a suitable theory to explain intention. The theory is suitable to explain any behavior requiring planning, such as entrepreneurship. One of the factors that might influence behavior is motivation. Motivation is assumed to be able to influence and shape an intention for a certain behavior. Intention is defined by three factors: An individual's attitude toward the specific behavior, subjective norms, and perceived behavioral control (Ajzen, 1991). An individual's attitude toward entrepreneurship is assessed based upon analysis on motivation to start a business, and therefore theoretically, a positive attitude toward entrepreneurship can be made as a requirement to assess one's intention to become an entrepreneur. In accordance with such a thought, the author conducted an analytical study to measure the degree of entrepreneurial intention, motivation, and personality traits with Venesaar et.al (2006) study as a reference.

Entrepreneurial intention of the final year students, in accordance with Kim Soon et.al (2016) is measured by using two dimensions, namely immediate term intention, which consists of 8 indicators, and future intention, which consists of 3 indicators. Student's entrepreneurial motivation is measured based on Venesaar et.al (2006), who divided entrepreneurial motivation variable into three dimensions, namely: Ambition for Freedom, which consists of 5 indicators, Self-realization (6 indicators), and Pushing Factors (3 indicators). Personality Traits and Other Characteristics according to Venesaar et.al (2006) are divided into four dimensions, namely Personality Trait with 9 indicators, Business Relation Dimension with 3 indicators, Behavior Dimension in Organization with 4 indicators, and Other Characteristics dimension with 3 indicators. This study uses the six-level Likert scale as its measurement, consisting of: Strongly Disagree, Disagree, Rather Disagree, Rather Agree, Agree, and Strongly Agree, since, as explained by Babin (2013) using under five categories is considered inappropriate, and that interval will only be considered as an interval scale if it has five or more categories.

\section{Research Method}

This study applies quantitative research approach, which is one that emphasizes on the measurement and sampling methods, since it applies hypothetic-deductive framework which stresses on detailed priority on the collection of data and analysis (Hair, Bush and Ortinau, 2003). Based on its aim, this study is a descriptive study to describe entrepreneurial intention, motivation and personality trait of the final year students of Undergraduate Program of the University of Indonesia in five faculties that host entrepreneurship subject. Benefit-wise, this study is a pure research or basic research, as it is based on intellectual reason, which aims to expand human knowledge, and not to make or create something (Syofian, 2017). Based on the period of research, this study is a cross-sectional research, 
where the data collection was conducted in certain time and location only. Based on the data collection technique, this research is categorized into survey study.

The population in this study is final year undergraduate students of the University of Indonesia from five faculties, namely Faculty of Economics and Business, Faculty of Administrative Science, Faculty of Pharmacy, Faculty of Engineering, and Faculty of Computer Science. The sample collection technique utilized is non-probability with quota sampling method. In quota sampling, data collector garnered units as samples in accordance with the "quota" (the determined sample criteria and number) which had been determined (Asra, 2017). This way, the researchers found 30 samples of each faculty that became the objects of study. This makes the total sample in this study to be 150 people. The researchers selected final year students, since there was possibility that they had not determined their future career and still looked for the available options. The students were selected from five faculties hosting entrepreneurship subject as there had been some studies scrutinizing the relations between entrepreneurial education with entrepreneurial intention, such as Krueger (1993); Reynold (1995); Thomas (1999); Simon et al (1999); Drnovsek and Glas (2001) in Thandi and Sharma (2003).

This study uses a descriptive statistic analysis which is a type of simple statistic commonly used by researchers to describe basic pattern in data (Neuman, 2000). The benefit of descriptive analysis, according to Umi Narimawati (2007), in developing a distribution frequency table, is to figure out whether the score level of research variable is categorized into good, fairly good, not really good or not good. This study applies interval scale, and therefore, uses mean value as a measurement to respondents' answers to the questionnaire, in order to make it easier for the researchers to interpret respondents' answers. To interpret respondents' answers, this study uses mean value which is divided into six categories. The categories consist of very low (1-1.83), low (1.84-2.66), fairly low (2.66-3.49), fairly high (3.49-4.32), high (4.32-5.15), and very high (5.15-6).

\section{Result and Discussion Descriptive Statistics}

The descriptive statistic analysis in this study is divided into several parts, namely descriptive statistic analysis of respondents' characteristics, descriptive statistic of entrepreneurial intention variable, descriptive statistic of entrepreneurial motivation, descriptive statistic of personality traits and other characteristics, and descriptive statistic of entrepreneurial intention, motivation, and personality traits by faculty. The following are the results of the descriptive statistic analysis on respondents' characteristics.

\section{Respondent's Year of Study}

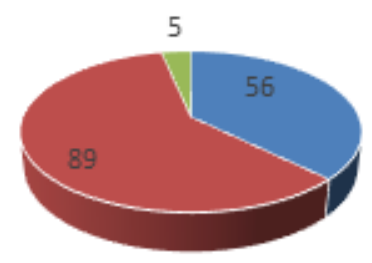

- Semester 5 (Extension) - Semester 7 - >Semester 7

Figure 3. Respondent's Length of Study

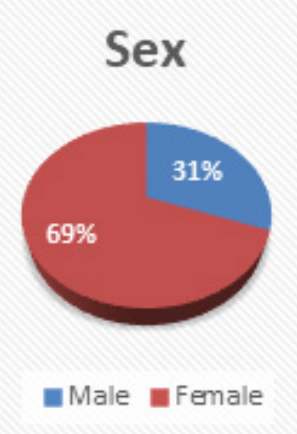

Figure 4. Respondent's Gender

Source: data primer 2018 
From the total respondents, there are 89 students attending 7 th semesters, 5 students more than 7 th semesters and 56 students attending $5^{\text {th }}$ semesters. When viewed from the gender profile, there are 46 people or about $30.7 \%$ are male, and the other is $69 \%$ or 104 students is male.

Table 1. Descriptive Statistic on Respondents' Characteristics $(n=150)$

\begin{tabular}{llll}
\hline Category & Fre- & $\begin{array}{l}\text { Percen- } \\
\text { quency } \\
\text { tage }\end{array}$ \\
\hline Major & $\begin{array}{l}\text { Faculty of Economics } \\
\text { and Business }\end{array}$ & 30 & $20 \%$ \\
& $\begin{array}{l}\text { Faculty of Administra- } \\
\text { tive Science }\end{array}$ & 30 & $20 \%$ \\
& Faculty of Pharmacy & 30 & $20 \%$ \\
& Faculty of Computer & 30 & $20 \%$ \\
& Science & & \\
& Faculty of Engineering & 30 & $20 \%$ \\
\hline Current & Semester 5 (Extension) & 56 & $37.3 \%$ \\
Semester & Semester 7 & 89 & $59.3 \%$ \\
& $>$ Semester 7 & 5 & $3.3 \%$ \\
\hline Sex & Male & 46 & $30.7 \%$ \\
& Female & 104 & $69.3 \%$ \\
\hline Parents' & Entrepreneur & 38 & $25 \cdot 3 \%$ \\
Occupation & Private Employee & 50 & $33.3 \%$ \\
& Civil Servant & 39 & $26 \%$ \\
& Others & 23 & $15.3 \%$ \\
\hline
\end{tabular}

Source: Data processing result using SPSS 23.0 (2017)

The descriptive statistic analysis result on respondents' characteristics shows that the respondents from the five faculties have the same frequency, as this study applies non-probability quota sampling with 30 respondents as its quota from each faculty, and thus the total respondents amount 150 people. The highest number of respondents are those in their 7 th semester, and the respondents in this study were predominantly women, and according to parents' occupation, the majority of respondents' parents were private employees.

In this study, descriptive statistic analysis on research variables is conducted by applying mean calculation from respondents' answers which are grouped into 6 categories, from very low to very high. The following are the results of the descriptive statistic data processing on research variables based on certain indicators:

\begin{tabular}{|c|c|c|}
\hline $\begin{array}{l}\text { Entrepreneur- } \\
\text { ial Motivation } \\
\text { Variable }\end{array}$ & Mean & Description \\
\hline \multicolumn{3}{|c|}{ Ambition for Freedom Dimension } \\
\hline $\begin{array}{l}\text { I want to be free } \\
\text { to do my activ- } \\
\text { ities }\end{array}$ & 5.17 & Very high \\
\hline $\begin{array}{l}\text { I want to have my } \\
\text { own business }\end{array}$ & 4.89 & High \\
\hline $\begin{array}{l}\text { I feel more re- } \\
\text { spected if I have } \\
\text { my own company }\end{array}$ & 4.44 & High \\
\hline $\begin{array}{l}\text { I want to im- } \\
\text { plement new } \\
\text { ideas in my own } \\
\text { business }\end{array}$ & 4.81 & High \\
\hline $\begin{array}{l}\text { I want to develop } \\
\text { my hobby into } \\
\text { business }\end{array}$ & 4.77 & High \\
\hline $\begin{array}{l}\text { Total Mean } \\
\text { of Ambition } \\
\text { for Freedom } \\
\text { Dimension }\end{array}$ & 4.82 & High \\
\hline \multicolumn{3}{|c|}{ Self-realization Dimension } \\
\hline $\begin{array}{l}\text { I want to have a } \\
\text { better position in } \\
\text { the community }\end{array}$ & 5.06 & High \\
\hline $\begin{array}{l}\text { I want to chal- } \\
\text { lenge myself } \\
\text { to become an } \\
\text { entrepreneur }\end{array}$ & 4.59 & High \\
\hline $\begin{array}{l}\text { I want to moti- } \\
\text { vate other people }\end{array}$ & 4.95 & High \\
\hline $\begin{array}{l}\text { I want to lead } \\
\text { other people }\end{array}$ & 4.72 & High \\
\hline $\begin{array}{l}\text { I want to con- } \\
\text { tinue my family } \\
\text { tradition }\end{array}$ & 3.69 & Fairly High \\
\hline $\begin{array}{l}\text { I want to become } \\
\text { like my idol }\end{array}$ & 4.60 & High \\
\hline $\begin{array}{l}\text { Total Mean of } \\
\text { Self-realization } \\
\text { Dimension }\end{array}$ & 4.60 & High \\
\hline \multicolumn{3}{|c|}{ Pushing Factors Dimension } \\
\hline $\begin{array}{l}\text { I want to become } \\
\text { an entrepreneur } \\
\text { if I get fired }\end{array}$ & $4 \cdot 34$ & High \\
\hline $\begin{array}{l}\text { By being an en- } \\
\text { trepreneur, I will } \\
\text { get better income }\end{array}$ & 4.65 & High \\
\hline
\end{tabular}




\begin{tabular}{|l|l|l|}
\hline $\begin{array}{l}\text { I want to become } \\
\text { an entrepreneur } \\
\text { if I am unsatisfied } \\
\text { with my job }\end{array}$ & 4.37 & High \\
\hline $\begin{array}{l}\text { Total Mean of } \\
\text { Pushing Factors } \\
\text { Dimension }\end{array}$ & 4.45 & High \\
\hline $\begin{array}{l}\text { Total Mean } \\
\text { Value of Moti- } \\
\text { vation Variable }\end{array}$ & $\mathbf{4 . 6 2}$ & High \\
\hline
\end{tabular}

Source: Data processing result using SPSS 23.0 (2017)

According to the data processing result on entrepreneurial intention variable, it can be seen that the entrepreneurial intention of the final year students is high, with the total mean of 4.40 , and when observed according to dimension, the immediate term intention is fairly high, with mean value of 4.22 , and so is the future intention dimension, with mean value of 4.59 , which is categorized as high.

Based on the data processing result of entrepreneurial motivation variable, it can be seen that the mean value of the overall dimensions of motivation variable is 4.62 , which is categorized as high, with the highest mean value lies at Ambition for Freedom, with 4.82, which is also categorized as high. Selfrealization dimension scores 4.60 as its mean, which is categorized as high, while the dimension with lowest mean in this variable is pushing factors, which scores 4.45, which is also categorized as high.

Based on the measurement of mean value of the four dimensionsin Personality Traits and Other Characteristics Variable, the overall mean value of the entire dimensions of Personality Traits and Other Characteristics Variable is 4.56 , which is categorized as high.

Table 3. Descriptive Statistics of Intention, Motivation, and Personality Traits Variables by Faculty

Personality Traits dimension is the dimension with the highest mean, which is 4.86 , which is categorized as high. Afterwards, the second highest dimension is Business Relation Dimension, with mean value of 4.62 , or categorized as high. The third highest dimension is Behavior in Organization Dimension, with mean value of 4.57 , which is also categorized as high. The lowest dimension is Other Characteristics Dimension, with mean value of 4.19 , which is categorized as fairly high.

Table 3. Descriptive Statistics of Intention, Motivation, and Personality Traits Variables by Faculty

\begin{tabular}{|c|c|c|c|c|c|c|c|}
\hline \multirow[t]{2}{*}{ Variable } & \multirow[t]{2}{*}{ Dimension } & \multicolumn{5}{|c|}{ Faculty } & \multirow[t]{2}{*}{ Total } \\
\hline & & $\begin{array}{c}\text { Faculty of } \\
\text { Economics and } \\
\text { Business }\end{array}$ & $\begin{array}{c}\text { Faculty of } \\
\text { Administrative } \\
\text { Science }\end{array}$ & $\begin{array}{l}\text { Faculty of } \\
\text { Pharmacy }\end{array}$ & $\begin{array}{c}\text { Faculty of } \\
\text { Computer } \\
\text { Science }\end{array}$ & $\begin{array}{l}\text { Faculty of } \\
\text { Engineering }\end{array}$ & \\
\hline \multirow[t]{2}{*}{$\begin{array}{l}\text { Entrepreneur- } \\
\text { ial Intention }\end{array}$} & $\begin{array}{l}\text { Immediate } \\
\text { Term Intention }\end{array}$ & 4.17 & 4.79 & 4.19 & 4.09 & 3.87 & 4.22 \\
\hline & Future Intention & 4.36 & 5.02 & 4.5 & 4.64 & 4.42 & 4.59 \\
\hline \multicolumn{2}{|c|}{ Total Mean by Faculty } & 4.26 & 4.90 & 4.34 & 4.36 & 4.14 & 4.40 \\
\hline \multirow[t]{3}{*}{$\begin{array}{l}\text { Entrepreneur- } \\
\text { ial Motivation }\end{array}$} & $\begin{array}{l}\text { Ambition for } \\
\text { Freedom }\end{array}$ & 4.59 & 5.1 & 4.81 & 4.73 & 4.84 & 4.82 \\
\hline & Self-realization & 4.46 & 4.79 & 4.54 & 4.59 & 4.63 & 4.6 \\
\hline & Pushing Factors & 4.15 & 4.54 & 4.47 & 4.54 & 4.57 & 4.45 \\
\hline \multicolumn{2}{|c|}{ Total Mean by Faculty } & 4.4 & 4.81 & 4.61 & 4.62 & 4.68 & 4.62 \\
\hline \multirow{4}{*}{$\begin{array}{l}\text { Personality } \\
\text { Traits and } \\
\text { Other Charac- } \\
\text { teristics }\end{array}$} & $\begin{array}{l}\text { Personality } \\
\text { Traits }\end{array}$ & 4.76 & 5 & 4.87 & 4.94 & 4.71 & 4.86 \\
\hline & $\begin{array}{l}\text { Business Rela- } \\
\text { tion }\end{array}$ & 4.67 & 4.77 & 4.73 & 4.57 & $4 \cdot 34$ & 4.62 \\
\hline & $\begin{array}{l}\text {-Behavior in } \\
\text { Organization }\end{array}$ & 4.62 & 4.72 & 4.66 & 4.54 & $4 \cdot 31$ & 4.57 \\
\hline & $\begin{array}{l}\text { Other Charac- } \\
\text { teristics }\end{array}$ & 4.03 & 4.26 & $4 \cdot 36$ & 4.06 & 4.24 & 4.19 \\
\hline
\end{tabular}




\begin{tabular}{lllllll}
\hline $\begin{array}{l}\text { Total Mean by } \\
\text { Faculty }\end{array}$ & 4.52 & 4.69 & 4.65 & 4.53 & 4.4 & 4.56 \\
\hline
\end{tabular}

According to the data processing result of the research variable by faculty, it can be seen that the highest entrepreneurial mean in intention was found among students of the Faculty of Administrative Science, with mean value of 4.9 , which is categorized as high, while faculty with the lowest mean in entrepreneurial intention variable is Faculty of Engineering, with a total mean of 4.14, which is categorized as fairly high. As to regarding entrepreneurial motivation variable, the highest mean was found in Faculty of Administrative Science, with the total mean value of 4.81 , which is categorized as high, while faculty with the lowest total mean is Faculty of Economics and Business, with the total mean of 4.4, which is categorized as high. Regarding personality traits and other characteristics variable, it can be seen that the highest mean value was found in the Faculty of Administrative Sciences, with the total mean value of 4.69 , which is categorized as high, while faculty with the lowest total mean in the same variable was Faculty of Engineering, with the total mean of 4.4 , or categorized as high.

\section{DISCUSSION}

The result of descriptive statistic data processing on entrepreneurial intention variable revealed that the entrepreneurial intention of the final year students can be categorized as high, yet when it is observed according to the dimension, these final year students of the University of Indonesia show higher intention to become entrepreneur in long term, which is proven by the higher mean of Future Intention dimension, which is 4.59, as compared to Immediate Term Intention Dimension, which total mean is 4.22 , which is categorized as fairly high. This is still below Future Intention
Dimension, which is categorized as high. Furthermore, this also shows that the final year students of University of Indonesia prefer to become entrepreneur in long term instead of in the near future, since when it is seen on the indicators in Immediate Term Intention Dimension, there are several indicators that fall into fairly high category, such as "I prefer to become an entrepreneur rather than corporate employee", "I aspire to become an entrepreneur", "I think of starting a business after completing education." The mean value of the indicator is rather low, thus this shows that the final year students of the University of Indonesia prefer to work as an employee rather than to become an entrepreneur. They don't think yet of starting a business right after completing their education, and entrepreneurship is not their first dream job or aspiration. They choose instead to become entrepreneur in the future, which is proven by the mean of the three future intention indicators showing their statements, which are categorized as high. It can be therefore concluded that the mean result of the two dimensions of entrepreneurial intention variable, which is 4.40 , falls into high category.

The analysis result of the entrepreneurial motivation variable shows that the entrepreneurial motivation of the final year students fall into high category, with ambition for freedom scoring the highest. This result resonates with Venesaar's study (2006) which shows that ambition for freedom is the most influential dimension in this variable. When observed by indicators, there are five indicators in motivation variable that bring most influence to the final year students of the University of Indonesia, namely the desire to be free in doing their activities, desire to have their own business, desire to implement 
new ideas in their own business, desire to have a better position in community, and desire to motivate other people. These are the most influencing factors for students to start becoming an entrepreneur. The lowest indicator is found on the desire to continue family's tradition, and hence it shows that the factor that motivates them to start doing business is not any desire to continue family's tradition, or their family background in business.

The result from the analysis on the personality traitsand other characteristics variableshows that this traitofthestudents that are related to entrepreneurship falls into high category, with personality trait dimension dominates, with the highest total mean. This further shows that the personality trait of the final year students associated with entrepreneurship is high. The most influencing indicator in this variable is desire to succeed, ability to make decision and be held accountable for it, hardworking, belief in their own capability, and ability to collaborate with other people. Not afraid of getting loan is an indicator with the lowest mean, showing that the final year students of the University of Indonesia are still afraid of taking loan to start a business. This is in line with Venesaar's study (2006) which shows the lowest mean in this indicator.

Based on the data processing result of the variable by faculty, it can be seen that the highest value of total mean of intention to become entrepreneur variable falls in the Faculty of Administrative Science, with the total mean value of 4.9 , which falls into high category. However, when observed by dimension, the immediate term intention and future intention of the final year students of the Faculty of Administrative Science fall into high category. However, it can be further observed that the higher final value of the mean future intention than the immediate term intention indicates that the final year students of the faculty tend to intend to become entrepreneur in the far future, rather than in the near future. The faculty with the second highest mean value is Faculty of Computer Science with the total mean of 4.36 , followed by Faculty of Pharmacy, with 4.34 value, and Faculty of Economics and Business, with the total mean of 4.26. The faculty with the lowest total mean in the intention to become entrepreneur variable is Faculty of Engineering with the total mean of 4.14. When observed by dimension, the immediate term intention falls into fairly high category, while the future intention dimension falls into high category. It can be therefore seen that the final year students in the Faculty of Engineering tend to intend to become entrepreneur in long term.

Based on the data processing result by faculty, it can be seen that the highest mean value of intention to become entrepreneur variable is found in the Faculty of Administrative Science with the total mean of 4.81 , which falls into high category. However, when observed by dimension, the ambition for freedom dimension has the highest mean value, which is 5.1, which falls into high category. Afterwards, the faculties with the highest mean value in sequence are Faculty of Engineering, Faculty of Computer Science, and Faculty of Pharmacy, with the mean value of $4.68,4.62$, and 4.61 , respectively. The faculty with the lowest total mean value is Faculty of Economics and Business, with the total mean of 4.4 , which falls into high category, and has the highest mean value in ambition for freedom dimension, which is 4.59, which falls into high category.

Based on the data processing result of personality traits and other characteristics by faculty, it can be seen that the highest mean value is found in the Faculty of Administrative Science with the total mean of 4.69 , which falls into high category. However, when observed 
by dimension, the dimension with the highest mean value is personality traits with the mean value of 5 , which falls into high category. This means that the final year students of the Faculty of Administrative Sciences possess high entrepreneurial personality traits. Afterwards, the faculty with the second highest total mean value is Faculty of Pharmacy, with the total mean value of 4.65, followed by Faculty of Computer Science with the total value of 4.53, and Faculty of Economics and Business, with the total mean of 4.52 . The faculty with the lowest total mean value is Faculty of Engineering with the total mean value of 4.4. When observed by dimension, the personality traits of the final year students of the Faculty of Engineering have the highest mean value, which is 4.71, which falls into high category, which indicates that the final year students of the Faculty of Engineering have high entrepreneurial personality traits.

\section{CONCLUSION}

Based on the result of researching Entrepreneurial Intention, Motivation and Personality Traits of the final year students of the undergraduate program of the University of Indonesia from Faculty of Economics, Faculty of Administrative Science, Faculty of Pharmacy, Faculty of Computer Science, and Faculty of Engineering, it can be concluded that:

- The intention to become entrepreneur of the final year students of the Undergraduate Program of the University of Indonesia from the Faculty of Economics, Faculty of Administrative Science, Faculty of Pharmacy, Faculty of Computer Science, and Faculty of Engineering fall into high category.

- The motivation to become entrepreneur of the final year students of the Undergraduate Program of the University of Indonesia from the Faculty of Economics, Faculty of Administrative Science, Faculty of Pharmacy, Faculty of Computer Science, and Faculty of Engineering fall into high category.

- The entrepreneurial personality traits of the final year students of the undergraduate program of the University of Indonesia from the Faculty of Economics, Faculty of Administrative Science, Faculty of Pharmacy, Faculty of Computer Science, and Faculty of Engineering fall into high category.

\section{REFERENCES}

Ajzen, Icek. 1991. Theory of Planned Behavior. Organizational Behavior and Human Decision Processes, Vol. 50, Issue 2, p: 179-211

Alma, Buchari. 2011. Kewirausahaan untuk Mahasiswa dan Umum. Bandung: Alfabeta

Asra, Abuzar dan Achmad Prasetyo. 2015. Pengambilan Sampel Dalam Penelitian Survei. Jakarta: PT. Raja Grafindo Persada

Babin, Zikmund. 2013. Essentials of Marketing Research 5th Edition. Cengage.

Davidson, P. 1995. Determinants of entrepreneurial intentions. Paper presented at the RENT IX Workshop. November 23-24, Piacenza, Italy.

Etzkowitz, H. 2004. The evolution of Entreprenerial University, International Journal of Technology and Globalisation, 1 (1), p. 64-77.

Fayolle, Alain., Redford, Dana T. 2014. Handbook on the Entrepreneurial University, Edward Elgar Publishing Limited, Cheltenham, UK

Fuadi, I. F. 2009. "Hubungan minat berwirausaha dengan prestasi praktik kerja industri siswa kelas 
XII Teknik Otomotif SMK Negri 1 Adiwerna Kabupaten Tegal." Jurnal PTM, Vol. 9, Desember 2009, 92-98.

Galloway, Laura dan Steve Kelly. 2009. "Identifying Entrepreneurial Potential? An Investigation of the Identifiers and Features of Entrepreneurship". International Review of Entrepreneurship Vol.7.

Hair, Joseph F., Robert P. Bush, David J. Ortinau. 2003. Marketing Research Within a Changing Information Environment. Second Editions, New York : McGraw-Hill.

HarshanaHYPERLINK "http://www. emeraldinsight.com/author/ Kasseeah\% $2 \mathrm{C}+\mathrm{H}$ arsh an a" HYPERLINK "http://www. emeraldinsight.com/author/ Kasseeah\%2C+Harshana"Kasseeah. 2016. "Investigating the impact of entrepreneurship on economic development: a regional analysis", Journal of Small Business and Enterprise Development, Vol. 23 Issue: 3 , pp. 896-916

Krueger, N.F. Jr, Reilly, M.D. and Carsrud, A.L. 2000. "Competing models of entrepreneurial intentions", Journal of Business Venturing, Vol. 15 No.5/6, pp. 41132.

Ng, Kim-Soon, Ahmad, Abd Rahman dan Nurul Nadia Ibrahim. $2016 . \quad$ "Undergraduates' Entrepreneurial Motivation and Entrepreneurship Career Intention at a Public. University", Journal of Entrepreneurship: Research \& Practice, Vol. 2016.

Naufal, Abdillah., Sakapurnama, Eko. 2017. Link and Match Learning Outcomes of Entrepreneurial Competencies Required in Indonesian Companies, Turkish Online Journal of Educational Technology, November 2017,
Special Issue for IETC 2017, 466472

Kevin, Philpott., Lawrence, Dooley., Caroline, O’Reilly., Gary, Lupton. 2011. The Entrepreneurial University: Examining The Underlying Academic Tensions, Technovation, Volume 31, Issue 4, April 2011, Pages 161-170, [online]: https://ac.els-cdn.com/ So166497210001331/1-s2.0So166497210001331-main.pdf? tid $=5039 \mathrm{c} 37 \mathrm{e}-08 \mathrm{~d} 3-$

11 e $8-9$ b 73 - 0 o o o o a a b of 27 HYPERLINK

"https://ac.els-cdn.com/

So166497210001331/1-s2.o-

So166497210001331-main.pdf?

tid $=5039$ c $37 \mathrm{e}-08 \mathrm{~d} 3-1$

$1 \mathrm{e} 8-9 \mathrm{~b} 7300$

oooaabof27\&acdnat

$=1517656611$

ca4cfe3950041ae57ea

$720012147 \mathrm{c} 7 \mathrm{aa} " \&$

HYPERLINK-“https://

ac.els-cdn.com/

So166497210001331/1-s2.o-

So166497210001331-main.pdf?_

tid $=5039$ c37e-08d 3-11e 8-9b73-

oooooaabof $27 \&$ acdnat $=$

1517656611_-

ca4cfe3950041ae57ea

$720012147 \mathrm{c} 7 \mathrm{aa} "$

acdnat $=1517656611$

ca4cfe 39500

41ae57ea720e12147c7aa

Putranto, I.J., Sakapurnama, E. 2016. Measuring entrepreneurship profiles in higher education, case study in Universitas Indonesia. Turkish Online Journal of Educational Technology. Hal 95100.

Lawrence Neuman, William. 2000. Social Research Methods, Qualitative and Quantitative Approach, 4th Edition. USA:Allyn \& Bacon. 
Robbins, Stephen P., B. Rolf, I. Stagg dan Coulter, Mary. 2015. Management. Pearson Education, Australia.

Schumpeter,J.A.1934.Entrepreneurship in Economic Development: an Inquiry into Profits, Capital, Credit, Interest, and The Business Cycle. Oxford University Press, New York. Siregar, Ir. Syofian. 2017. Metode Penelitian Kuantitatif. Jakarta: Prenada Media Grup.

Venesaar, Ene. 2006. Students' Attitudes and Intentions toward Entrepreneurship at Tallinn University of Technology. TUTWPE Working Papers. (154), 97-114.

Website:

www.belmawa.ristekdikti.go.id (Accessed on Sunday, 17 September at 11.12)

http://www.depkop.go.id/content/ $\mathrm{read} / \mathrm{ratio}$-wirausaha-indonesianaik-jadi-31-persen/ (Accessed on 2 June 2017 at 16.21)

https://own.ui.ac.id/index.php/ s/9RaUaDhchqy7ugc\#pdfviewer (Accessed on 17 September at 9.07) 